\title{
Research on Forecasting of Traffic Volume of Heilongjiang Bridge
}

\author{
Rui Hua
}

No.1 Xuehai Street, School of Management, Harbin University of Commerce, Songbei District, Harbin, China

hsdglxyhr@126.com

Keywords: Heilongjiang bridge; Traffic volume; EVIEWS

\begin{abstract}
The construction of the Heilongjiang Bridge is an important international channel connecting the Heihe River and the Russia Brisbane. The construction of the Heilongjiang Bridge is of great significance to strengthening the trade between China and Russia and promoting the economic and social development between China and Russia. It is very important to understand the influence of the construction of Heilongjiang Bridge on the traffic volume, and to design the relevant management system of the Heilongjiang Bridge, so as to better promote the regional social and economic development.
\end{abstract}

\section{Introduction}

Since the recovery of the border trade between the former Soviet Union and the Amur border in the Heihe-Blagoveshchensk port in 1987, the number of persons and cargoes crossing the border increased sharply, Especially in 21st century, along with the continuing heating up of political and economic relations between China and Russia, the Sino-Russian trade has become increasingly closer, making the Heihe port more prominent. But the backwardness of its existing international channels has become a bottleneck in the development of Sino-Russian economic and trade cooperation. Therefore, it is necessary to establish the "Heilongjiang bridge" in 2016. It is of great practical significance to understand the possible changes of the traffic volume brought by the completion of the Heilongjiang Bridge and to plan the relevant facilities and programs of the Heilongjiang Bridge in order to play a better role in promoting the regional economic and social development of the Heilongjiang Bridge.

\section{Understanding of Economic Variables}

Heilongjiang highway bridge is a world bridge built between Russia and Heilongjiang China River (Amur River), the traffic volume is mainly determined by the resulting from the Sino Russian economic and trade activities of transit passenger and freight volume. Therefore, we use EVIEWS software to forecast the freight volume, passenger volume and traffic volume of Heihe port in this project, The economic variables are explained as follows:

(1)Freight volume of Heihe port: The freight volume of Heihe port is HY, using linear regression model to forecast the freight volume of Heihe port.

(2)The passenger volume of Heihe port: The passenger volume of Heihe port is KY, using the index smoothing technology to forecast the passenger volume of Heihe port.

(3)The traffic volume of Heihe port: According to the Heihe port at present, the main model of motor transport is converted into a passenger car to calculate the traffic volume of the Heilongjiang highway bridge. The traffic volume of Heihe port is the sum of passenger traffic volume and freight traffic volume.

\section{The Forecast of Passenger and Freight Volume of Heilongjiang Highway Bridge}

The development of passenger and freight traffic of Heilongjiang Highway Bridge is mainly related to the total quantity and trend of border trade, personnel exchanges and economic and technological cooperation projects between China and Russia. 
The development forecast of passenger and cargo traffic volume of Heilongjiang Highway Bridge is composed of three parts:

(1) It is a research on the transit passenger and cargo transportation volume of Heihe, Sunwu and Xunke etc in the past ten years, and establishes the mathematical model to forecast the future development trend of the traffic volume. (which is trend growth traffic volume)(2) After the completion of the bridge, Sino-Russian economic, technical, trade and resource development projects will be actively promoted, which will induce the increase of transport demand between China and Russia. (3) After the completion of the Heilongjiang Highway Bridge, Heihe Port traffic conditions will be fundamentally improved, thus attracting Heilongjiang Province and other parts of the country and the Russian Far East and CIS countries, trade, traffic, resulting in the transfer of traffic. The passenger traffic forecast of Heilongjiang Highway Bridge mainly refers to the forecast of its growth trend, using the exponential smoothing method. To forecast the traffic volume of Heilongjiang Highway Bridge, which needs forecasting the trend growth, predicting the volume of induced traffic and forecasting the increment of transfer volume, forecasting the linear regression model based on GDP, predicting the induced traffic volume based on the $15 \%$ guarantee ratio, Prediction of Transfer Increment for 90\% Reflux in Drainage Volume during.

Forecast of Passenger Volume of Heilongjiang Highway Bridge. Suppose that the passenger volume KY satisfies the first-order autoregressive model with the intercept term in time series to predict the passenger volume in the next $\mathrm{N}$ years. EVIEWS software is used to forecast the passenger volume.

\begin{tabular}{cccc}
\multicolumn{4}{c}{ Table 1 } \\
year & $\begin{array}{c}\text { Entry and exit/ } \\
\text { Million people }\end{array}$ & $\begin{array}{c}\text { Entry/Million } \\
\text { people }\end{array}$ & $\begin{array}{c}\text { exit/ Million } \\
\text { people }\end{array}$ \\
\hline 2000 & 57.1 & 28.5 & 28.6 \\
2001 & 51 & 26.4 & 24.6 \\
2002 & 45.2 & 22.6 & 22.6 \\
2003 & 41.8 & 20.8 & 21 \\
2004 & 62.7 & 31.2 & 31.5 \\
2005 & 96.3 & 48.1 & 48.2 \\
2006 & 108.9 & 54.4 & 54.5 \\
2007 & 124.7 & 62.3 & 62.4 \\
2008 & 138.7 & 69.4 & 69.3 \\
2009 & 86.7 & 43.3 & 43.4 \\
2010 & 104.4 & 52.2 & 52.2 \\
\hline
\end{tabular}

(Source: According to customs statistics)

The first order autoregressive model is established: $k y=a+b * k y(-1)$ 


\begin{tabular}{ccccc}
\hline \hline & Coefficien & & \\
Variable & $\mathrm{t}$ & Std. Error & t-Statistic & Prob. \\
\hline \hline C & 24.56979 & 19.69989 & 1.247205 & 0.2476 \\
KY(-1) & 0.755998 & 0.224471 & 3.367909 & 0.0098 \\
\hline \hline & & Mean dependent & \\
R-squared & 0.586410 & var & 86.04000 \\
Adjusted R-squared & 0.534711 & S.D. dependent var & 34.36840 \\
& & Akaike info & \\
S.E. of regression & 23.44341 & criterion & 9.323913 \\
Sum squared resid & 4396.749 & Schwarz criterion & 9.384430 \\
Log likelihood & -44.61956 & Hannan-Quinn & \\
F-statistic & 11.34281 & Durbin-Watson stat & 1.875170 \\
Prob(F-statistic) & 0.009816 & & 9.257526 \\
\hline \hline
\end{tabular}

Figure 1. Autoregressive results for KY

So the autoregressive equation of Heihe passenger volume is obtained: $\mathrm{ky}=24.569794+0.755998$ $\operatorname{ky}(-1)$

Forecasting the passenger volume of the Heihe River in the past years and the autoregressive forecasting passenger volume, As shown in Table 2 below:

Table 2 Forecast of passenger volume

\begin{tabular}{cc}
\hline year & $\begin{array}{c}\text { Passenger traffic / Million } \\
\text { people }\end{array}$ \\
\hline 2015 & 102.9 \\
2020 & 102.5 \\
2025 & 102.4 \\
2030 & 102.4 \\
\hline
\end{tabular}

Heilongjiang Highway Bridge over the Trend of Growth Forecast. Suppose that the freight quantity HY satisfies the first-order autoregressive model with intercept term in the time series to forecast the freight volume in the next $\mathrm{N}$ years. EVIEWS software is used to forecast the freight volume. 
Table 3 Freight Traffic of Heihe City Port (10,000 tons)

\begin{tabular}{|c|c|c|c|}
\hline year & $\begin{array}{c}\text { import and } \\
\text { export }\end{array}$ & import & export \\
\hline 2000 & 34.2 & 31.3 & 2.9 \\
\hline 2001 & 31.8 & 26.5 & 5.3 \\
\hline 2002 & 19.7 & 13.6 & 6.1 \\
\hline 2003 & 21.6 & 13.5 & 8.1 \\
\hline 2004 & 37.2 & 25.3 & 11.9 \\
\hline 2005 & 44.3 & 31.5 & 12.8 \\
\hline 2006 & 29.6 & 12.9 & 16.7 \\
\hline 2007 & 37.8 & 10.6 & 27.2 \\
\hline 2008 & 33.7 & 6.1 & 27.6 \\
\hline 2009 & 20.7 & 5.7 & 15 \\
\hline 2010 & 22.9 & 7.7 & 15.2 \\
\hline
\end{tabular}

(Source: According to customs statistics)

The first-order autoregressive model is established: hy=a+b*hy(-1)

\begin{tabular}{ccccc}
\hline \hline & Coefficien & & \\
Variable & $\mathrm{t}$ & Std. Error & $\mathrm{t}$-Statistic & Prob. \\
\hline \hline C & 21.16443 & 11.28100 & 1.876113 & 0.0975 \\
HY(-1) & 0.282214 & 0.352341 & 0.800968 & 0.4463 \\
\hline \hline & \multicolumn{4}{c}{ Mean dependent } \\
R-squared & 0.074240 & var & 29.93000 \\
Adjusted R-squared & -0.041480 & S.D. dependent var & 8.483716 \\
& & Akaike info & \\
S.E. of regression & 8.657880 & criterion & 7.331673 \\
Sum squared resid & 599.6712 & Schwarz criterion & 7.392190 \\
& \multicolumn{4}{c}{ Hannan-Quinn } \\
Log likelihood & -34.65837 & criter. & 7.265286 \\
F-statistic & 0.641550 & Durbin-Watson stat & 1.734715 \\
Prob(F-statistic) & 0.446284 & & \\
\hline \hline
\end{tabular}

Figure 2. Autoregressive results for HY

So we get the autoregressive equation of Heihe freight volume: hy $=21.16443+0.282214$ hy $(-1)$ Based on the forecast of the freight volume in the Heihe River and the forecasted freight volume in the autoregressive period, as shown in Table 4 below: 


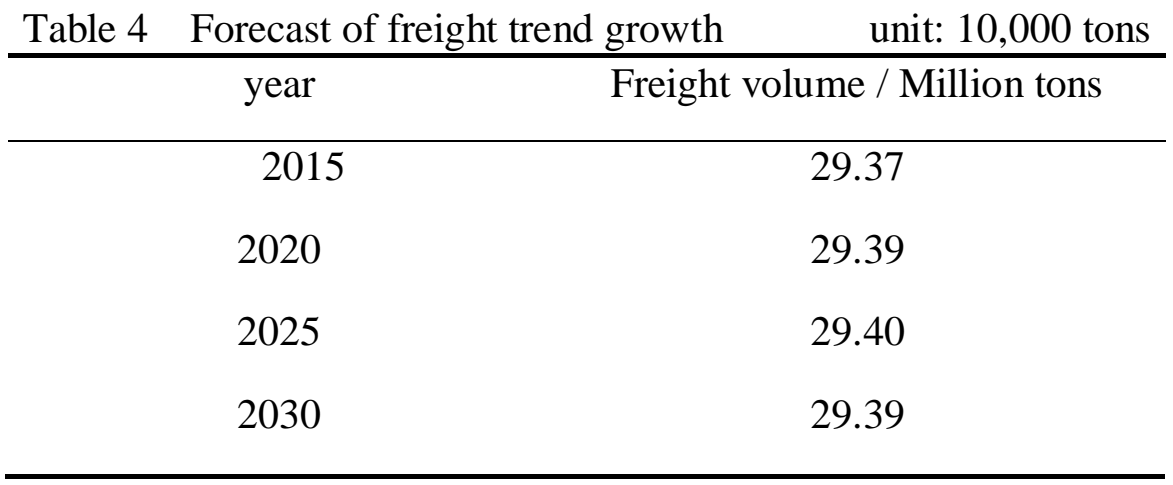

Heilongjiang Highway Bridge over Goods Induced Traffic Forecast. Heilongjiang highway bridge would have a positive role between China and Russia to promote cooperation in large projects, after it was opened to traffic.

Such as: (1) Amur - Heihe oil storage and transportation and refining integrated project (2) an annual output of 500,000 tons of cement grinding station construction projects(3) an annual output of iron powder 1 million tons of iron ore construction projects(4) annual production of about 800,000 cubic meters of timber mining and deep processing projects (5) Sino-Russian modern agricultural cooperation projects such as high-tech zones, etc.,

As a result of large projects between China and Russia, their raw materials and products trade will be transported through the Heilongjiang Highway Bridge, Therefore, the induced traffic volume of the Heilongjiang Highway Bridge is a comprehensive quantitative analysis and prediction of the development prospects and the flow direction of the trade volume of timber, crude oil, cement, agricultural products and other major items in the cooperation projects. Therefore, the induced traffic volume of the Heilongjiang Highway Bridge is a comprehensive quantitative analysis and prediction of the development prospects and the flow direction of the trade volume of timber, crude oil, cement, agricultural products and other major items in the cooperation projects. Summarize the forecast results of various goods, according to the guarantee rate of $15 \%$, get induced by the forecast of traffic results, as shown in Table 5 below.

Table 5 Induced traffic forecast table Unit: ten thousand tons

\begin{tabular}{|c|c|c|c|c|c|c|c|c|c|c|}
\hline year & $\begin{array}{c}\text { WOo } \\
\text { d }\end{array}$ & $\begin{array}{c}\text { crud } \\
\mathrm{e}\end{array}$ & $\begin{array}{l}\text { Gall } \\
\text { in } \\
\text { iron } \\
\text { ore }\end{array}$ & $\begin{array}{l}\text { Agricult } \\
\text { ural and } \\
\text { livestock } \\
\text { products }\end{array}$ & $\begin{array}{c}\text { Constructio } \\
\mathrm{n} \text { and } \\
\text { decoration } \\
\text { materials }\end{array}$ & $\begin{array}{c}\text { Light } \\
\text { industrial } \\
\text { and textile } \\
\text { products }\end{array}$ & $\begin{array}{c}\text { Ceme } \\
\text { nt } \\
\text { clinke } \\
\mathrm{r}\end{array}$ & $\begin{array}{c}\text { Elec } \\
\text { trolyt } \\
\text { ic } \\
\text { silica }\end{array}$ & total & $\begin{array}{c}\text { Gua } \\
\text { rante } \\
\text { ed } \\
\text { rate } \\
15 \%\end{array}$ \\
\hline $\begin{array}{c}201 \\
5\end{array}$ & 60 & 280 & 100 & 30 & 20 & 25 & 80 & 70 & 665 & 100 \\
\hline $\begin{array}{c}202 \\
0\end{array}$ & 90 & 350 & 100 & 50 & 20 & 40 & 100 & 100 & 850 & 128 \\
\hline $\begin{array}{c}202 \\
5\end{array}$ & 120 & 450 & 150 & 60 & 20 & 50 & 100 & 100 & $\begin{array}{c}107 \\
0\end{array}$ & 161 \\
\hline $\begin{array}{c}203 \\
0\end{array}$ & 150 & 600 & 220 & 80 & 20 & 60 & 100 & 100 & $\begin{array}{c}138 \\
0\end{array}$ & 207 \\
\hline
\end{tabular}

Heilongjiang Highway Bridge over the Cargo Transfer Forecast. As the Heihe tozagreb; Colombes; Payakumbuh; ports for seasonal ports, the average annual glacial period of about 115 days. During this period, trade and personnel exchanges between the two sides were greatly restricted. The cargo transportation was basically interrupted and they could only use hovercraft. Some foreign trade goods were diverted to other land border crossings such as Manchuria and 
Suifenhe. According to the relevant departments of China and Russia survey statistics, in recent years, the bulk of the goods and transported from the Heihe border to Manchuria and Suifen can be about 100 million tons. After the completion of the bridge, this part of the volume of traffic will be gradually transferred from the above two ports back to the Heihe port, can be used as a transfer of traffic to predict specific forecast results are shown in Table 6 below.

Table 6 Forecast of Transferred Transportation Unit: 10,000 tons

\begin{tabular}{ccc}
\hline year & $\begin{array}{c}\text { Freight volume / Million } \\
\text { tons }\end{array}$ & $\begin{array}{c}\text { Heihe port flow diversion } \\
\text { to other port traffic } \\
\text { volume }\end{array}$ \\
\hline 2015 & 29.37 & 12.16 \\
2020 & 29.39 & 12.17 \\
2025 & 29.40 & 12.17 \\
2030 & 29.39 & 12.17
\end{tabular}

Note: Transfer traffic $=($ normal traffic $/ 250$ days $) * 115$ days $* 0.9$, where 0.9 is a conservative factor.

Heilongjiang Highway Bridge Passenger and Cargo Traffic Forecast Results. According to the above forecast results, the forecast results of passenger and freight traffic of Heilongjiang Highway Bridge are summarized as follows: Table 7.

Table 7 Summary of Forecast Results of Passenger and Freight Traffic Volume of Heilongjiang Highway Bridge

\begin{tabular}{|c|c|c|c|c|c|}
\hline \multirow{2}{*}{ year } & \multirow{2}{*}{$\begin{array}{c}\text { Passenger traffic } \\
\text { (Million people })\end{array}$} & $\begin{array}{c}\text { Trend } \\
\text { volume }\end{array}$ & $\begin{array}{c}\text { induced } \\
\text { traffic } \\
\text { volume }\end{array}$ & $\begin{array}{c}\text { Transfer } \\
\text { volume }\end{array}$ & total \\
\cline { 3 - 6 } & 102.9 & 29.37 & 100 & 12.16 & 141.53 \\
\hline 2015 & 102.5 & 29.39 & 128 & 12.17 & 169.56 \\
\hline 2020 & 102.4 & 29.40 & 161 & 12.17 & 202.57 \\
\hline 2025 & 102.4 & 29.39 & 207 & 12.17 & 248.56 \\
\hline 2030 & & & & & \\
\hline
\end{tabular}

Heilongjiang Highway Bridge Traffic Forecast Results. According to the current Heihe port vehicle transport major models converted into small passenger cars through the Heilongjiang highway bridge traffic.

Passenger for small passenger cars, the conversion factor of 1.0, mainly for medium-sized freight cars, conversion factor of 1.5 . The actual load factor is $65 \%$ and the effective number of days of transportation is 306 days. The average daily traffic volume of each bridge is converted into the following formula:

Passenger traffic $=[$ Passenger traffic $\div(19 \times 306 \times 0.65)] \times 1.0$;

Freight traffic $=[$ Freight traffic $\div(5 \times 306 \times 0.65)] \times 1.5$;

Traffic volume $=$ passenger traffic + freight traffic volume.

The daily average traffic calculation results are shown in Table 8 below: 
Table 8 Forecast of traffic volume at Heihe Port

\begin{tabular}{cccccc}
\hline year & $\begin{array}{c}\text { Passenger } \\
\text { traffic / } \\
\text { Million } \\
\text { people }\end{array}$ & $\begin{array}{c}\text { Traffic } \\
\text { Volume } \\
\text { (vehicles / } \\
\text { day) }\end{array}$ & $\begin{array}{c}\text { Freight } \\
\text { volume / } \\
\text { tons }\end{array}$ & $\begin{array}{c}\text { Traffic } \\
\text { Volume } \\
\text { (vehicles / day) }\end{array}$ & total \\
\hline 2015 & 102.9 & 272 & 141.53 & 2135 & 2407 \\
2020 & 102.5 & 271 & 169.56 & 2557 & 2828 \\
2025 & 102.4 & 270 & 202.57 & 3055 & 3325 \\
2030 & 102.4 & 270 & 248.56 & 3749 & 4019 \\
\hline
\end{tabular}

Analysis of Prediction Results. From the above results can be seen in recent years, Heilongjiang Province, Heihe City, cargo, passenger volume and traffic volume showed a steady growth trend. Heilongjiang highway bridge is not only the main artery of the economic development of Heilongjiang Province, but also the indispensable force of the economic development of the country. The Heilongjiang highway bridge is not only the main artery of the economic development of Heilongjiang Province, but also the indispensable force of the economic development of Russia. In the process of international market economic integration and sustainable development of the concept of the harmonious development of the strategic level, the economic role of the Heilongjiang Highway Bridge is beyond doubt.

\section{Acknowledgements}

Science and Technology Project of the Department of Transportation of Heilongjiang Province: "The Assessment of the impact on Heilongjiang bridge construction on the regional social and economic" (Project No.: 2017001)

\section{References}

[1] Zhao Chuanjun. On the Establishment of Sino-Russia Free Trade Area. Social Science Literature Publishing House, 2010.

[2] Chen Xiaoguang. Five Major Programs of Heilongjiang Traffic Development. China Communications News, 2014.

[3] Zou Xiuting. The Impact of the Construction of the Eastern Russian Transportation Infrastructure on the Economic and Trade Cooperation between Heilongjiang Province and Russia. Siberian Studies, 2012.

[4] Wu Yan. Yearbook of Heihe - Chapter XII. Heihe Customs, 2012.

[5] Zhang Jie. On the Development Strategy of Heihe Port. Journal of Heihe, 2010

[6] Ma Xinhui. An Empirical Study on the Relationship between Transportation and Economic and Social Development - A Case Study of Heilongjiang Province. Learning and exploration, 2013.

[7] Официальный сайт: Федеральная служба государственной статистики. http://www.gks.ru 